\title{
Rola gminy w systemie organizacji i finansowania publicznego transportu zbiorowego
}

\author{
The Role of Local Self-government Units in the System \\ of the Organization and Financing Local Public Transport
}

Streszczenie. Zapewnienie publicznego transportu zbiorowego na szczeblu lokalnym należy do zadań własnych gminy. Zgodnie z przepisami ustawy z dnia 16 grudnia 2010 r. o publicznym transporcie zbiorowym zadanie to może być realizowane przez samorządowy zakład budżetowy, spółkę komunalną lub przez wykonawcę wybranego w trybie przepisów o zamówieniach publicznych bądź o koncesji na roboty budowlane lub usługi. Artykuł przedstawia ogólną charakterystykę organizacji i finansowania publicznego transportu zbiorowego na szczeblu gminy, realizowaną za pomocą wymienionych powyżej form organizacyjno-prawnych.

Słowa kluczowe: budżet; gmina; finansowanie; publiczny transport zbiorowy.

Abstract. The article describes the system of organization and financing of the local public transport in Poland. Providing local public transport is one of the tasks of local self-government units (called gmina). According to The Act on 
Public Transport of 2010 that task may be performed using different legal forms, e.g. budgetary entities or commercial companies established by local selfgovernments.

Keywords: budget; local self-government unit; financing; local public transport.

\section{Wprowadzenie}

Zaspokajanie zbiorowych potrzeb wspólnoty w zakresie lokalnego transportu zbiorowego stanowi, zgodnie z art. 7 ust. 1 pkt 4 ustawy o samorządzie gminnym ${ }^{1}$, zadanie własne gminy. Sposób jego realizacji, a w szczególności wybór formy organizacyjno-prawnej, w jakiej zadanie to będzie realizowane, zależy w każdym przypadku od miejscowych potrzeb i specyfiki konkretnej gminy, jej lokalizacji, powierzchni, liczby ludności. Zagadnienia związane z organizacją i finansowaniem publicznego transportu zbiorowego nabierają szczególnego znaczenia zwłaszcza w przypadku dużych gmin miejskich, gdzie każdego dnia ze środków komunikacji zbiorowej korzystają dziesiątki czy setki tysięcy pasażerów.

Przepisy regulujące organizację i funkcjonowanie publicznego transportu zbiorowego o zasięgu lokalnym (na obszarze gmin miejskich, miejsko-wiejskich, wiejskich) określa ustawa z dnia 16 grudnia 2010 r. o publicznym transporcie zbiorowym ${ }^{2}$. Zgodnie z założeniami ustawodawcy, nowe przepisy miały na celu zreformowanie modelu organizacji i funkcjonowania przewozów w transporcie publicznym, m.in. poprzez wprowadzenie instytucji organizatora oraz operatora publicznego transportu zbiorowego, a także planu zrównoważonego rozwoju publicznego transportu zbiorowego. Unormowanie kwestii związanych z publicznym transportem zbiorowym było istotne także ze względu na rosnące znaczenie i promocję tej formy komunikacji (m.in. w kontekście ochrony środowiska i polityki zrównoważonego rozwoju) oraz dynamicznie rozwijający

1 Ustawa z dnia 8 marca 1990 r. o samorządzie gminnym (tekst jedn. Dz.U. z 2013 r., poz. 594 ze zm.).

2 Dz.U. z 2011 r. Nr 5, poz. 13 ze zm., dalej: u.p.t.z. Ustawa weszła w życie z dniem 1 marca $2011 \mathrm{r}$. 
się rynek przedsiębiorców prywatnych, świadczących usługi przewozo$\mathrm{we}^{3}$.

Ustawę o p.t.z. stosuje się z uwzględnieniem aktów prawa europejskiego regulujących prowadzenie działalności transportowej. W zakresie przewozów o charakterze lokalnym będą to przepisy rozporządzenia (WE) nr 1370/2007 Parlamentu Europejskiego i Rady z dnia 23 października 2007 r. dotyczącego usług publicznych w zakresie kolejowego i drogowego transportu pasażerskiego oraz uchylającego rozporządzenia Rady (EWG) nr 1191/69 i (EWG) nr 1107/704.

W zakresie lokalnego publicznego transportu zbiorowego zastosowanie znajdują także przepisy ustawy Prawo przewozowe ${ }^{5}$ oraz ustawy o transporcie drogowym ${ }^{6}$ wraz $\mathrm{z}$ wydanymi na ich podstawie rozporządzeniami wykonawczymi.

Celem pracy jest ogólna charakterystyka aspektów organizacyjnych i prawnofinansowych związanych z wykonywaniem przez gminy zadań z zakresu publicznego transportu zbiorowego.

\section{Organizacja publicznego transportu zbiorowego na szczeblu gminy w świetle przepisów ustawy o publicznym transporcie zbiorowym}

Publiczny transport zbiorowy zdefiniowany został jako powszechnie dostępny, regularny przewóz osób wykonywany w określonych odstępach czasu po określonej linii (liniach) komunikacyjnej lub sieci komunikacyjnej (art. 4 ust. 1 pkt 14 u.p.t.z.). Gminne przewozy pasażerskie obejmują przewóz osób w ramach publicznego transportu zbiorowego, wykonywany w granicach administracyjnych jednej gminy lub gmin sąsiadujących,

3 Uzasadnienie do projektu ustawy o publicznym transporcie zbiorowym, Sejm RP VI kadencji, druk sejmowy nr 2916, s.1, http://orka.sejm.gov.pl/Druki6ka.nsf (dostęp: 26 maja 2013 r.).

4 Dz.Urz. UE (L) Nr 315 z dnia 3 grudnia 2007 r.

5 Ustawa z dnia 15 listopada 1984 r. Prawo przewozowe (tekst jedn. Dz.U. z 2012 r., poz. 1173 ze zm.).

6 Ustawa z dnia 6 września 2001 r. o transporcie drogowym (tekst jedn. Dz.U. z 2012 r., poz. 1265 ze zm.). 
które zawarły w tym przedmiocie porozumienie lub utworzyły związek międzygminny. W zakres gminnych przewozów pasażerskich wchodzi także komunikacja miejska, czyli przewozy wykonywane w granicach administracyjnych miasta, miasta i gminy, miast albo miast i gmin sąsiadujących.

Wyraźnemu rozgraniczeniu uległo wykonywanie zadań o charakterze organizatorskim i porządkowym w zakresie publicznego transportu zbiorowego od faktycznego prowadzenia działalności przewozowej. Służy temu wprowadzenie pojęć „organizatora publicznego transportu zbiorowego” (art. 4 ust. 1 pkt 9 u.p.t.z.) oraz „operatora publicznego transportu zbiorowego” (art. 4 ust. 1 pkt 8). W przypadku przewozów lokalnych rolę organizatora pełni właściwa jednostka samorządu terytorialnego (gmina). Organizator zapewnia funkcjonowanie publicznego transportu zbiorowego na obszarze swojej właściwości. Do jego zadań należy planowanie rozwoju, koordynowanie i zarządzanie publicznym transportem zbiorowym. W świetle art. 15 u.p.t.z. działania te obejmują w szczególności:

- dokonywanie badań i analiz potrzeb przewozowych w publicznym transporcie zbiorowym,

- zapewnienie odpowiednich standardów funkcjonowania transportu w zakresie infrastruktury technicznej (dworce, przystanki, węzły przesiadkowe), systemu taryfowo-biletowego oraz systemu informacji dla pasażerów,

- $\quad$ określanie przystanków komunikacyjnych i dworców,

- przygotowanie i przeprowadzenie postępowania zmierzającego do zawarcia umowy o świadczenie usług w zakresie publicznego transportu zbiorowego, a następnie zawarcie umowy z wybranym operatorem (operatorami),

- $\quad$ ustalanie opłat za przewóz oraz innych opłat (np. opłaty dodatkowej z tytułu nieposiadania przez pasażera odpowiedniego dokumentu przewozu),

- $\quad$ ustalanie sposobu dystrybucji biletów za usługę świadczoną przez operatora.

Operator publicznego transportu zbiorowego jest zaś podmiotem bezpośrednio realizującym zadania związane z komunikacją lokalną. 
Funkcję operatora może pełnić samorządowy zakład budżetowy lub przedsiębiorca uprawniony do prowadzenia działalności gospodarczej w zakresie przewozu osób, który zawarł z organizatorem umowę o świadczenie usług $\mathrm{w}$ zakresie publicznego transportu zbiorowego. Umowa ta przyznaje operatorowi prawo i jednocześnie zobowiązuje go do wykonywania usług przewozu o charakterze użyteczności publicznej. Wybór operatora innego niż samorządowy zakład budżetowy dokonywany jest w trybie ustawy Prawo zamówień publicznych ${ }^{7}$, ustawy o koncesji na roboty budowlane lub usługi ${ }^{8}$ albo poprzez bezpośrednie zawarcie umowy o świadczenie usług w zakresie publicznego transportu zbiorowego.

Umowa może zostać zawarta bezpośrednio przez organizatora (gminę) w trzech przypadkach. Po pierwsze, gdy średnia wartość roczna przedmiotu umowy jest mniejsza niż 1 mln euro lub świadczenie usług w zakresie publicznego transportu zbiorowego będzie się odbywało w wymiarze mniejszym niż 300 tys. km rocznie. Warunki te w przypadku dużych gmin miejskich nie są możliwe do spełnienia. Drugi przypadek obejmuje świadczenie usług przez podmiot wewnętrzny w rozumieniu rozporządzenia (WE) nr 1370/2007 powołany do świadczenia usług w zakresie transportu zbiorowego ${ }^{9}$. Podmiotem takim jest spółka utworzona przez j.s.t. w celu wykonywania zadań publicznych w zakresie lokalnego transportu zbiorowego, w której j.s.t. jest jedynym udziałowcem bądź akcjonariuszem ${ }^{10}$. Trzecia sytuacja, w której dopuszczalne jest bezpośrednie zawarcie umowy, wiąże się z wystąpieniem zakłóceń w świadczeniu usług $\mathrm{w}$ zakresie publicznego transportu zbiorowego (lub bezpośrednim ryzykiem wystąpienia takich zakłóceń), a nie jest możliwe za-

7 Ustawa z dnia 29 stycznia 2004 r. Prawo zamówień publicznych (tekst jedn. Dz.U. z 2013 r., poz. 907).

8 Ustawa z dnia 5 lutego 2009 r. o koncesji na roboty budowlane lub usługi (Dz.U. Nr 19, poz. 101 ze zm.).

9 Zgodnie z art. 2 lit. j rozporządzenia (WE) nr 1370/2007 podmiot wewnętrzny stanowi odrębną prawnie jednostkę podlegającą kontroli właściwego organu lokalnego, analogicznej do kontroli, jaką organ ten sprawuje nad własnymi służbami.

10 Jeżeli j.s.t. samodzielnie lub wspólnie $\mathrm{z}$ inną j.s.t. nie posiada $\mathrm{w}$ danym podmiocie wewnętrznym 100\% udziałów lub akcji, umowa o świadczenie usług w zakresie publicznego transportu zbiorowego powinna przyjąć formę koncesji na usługi (art. 22 ust. 5 u.p.t.z.). 
chowanie terminów określonych dla zawarcia umowy w innym trybie, np. przetargu lub udzielenia koncesji. Wybór przez gminę jednego z powyższych modeli - przetargowego, koncesyjnego, przekazania wykonywania zadań w sferze użyteczności publicznej spółce komunalnej lub samorządowemu zakładowi budżetowemu - zależne będzie przede wszystkim od wielkości gminy, jej charakteru (gmina miejska, miejsko-wiejska, wiejska) oraz skali zapotrzebowania na usługi w zakresie publicznego transportu zbiorowego.

Wybór formy organizacyjno-prawnej świadczenia usług w zakresie komunikacji zbiorowej będzie też wpływał na sposób i zakres ich finansowania ze środków budżetu gminy.

\section{3. Świadczenie usług w zakresie publicznego transportu zbiorowego przez samorządowy zakład budżetowy}

Samorządowe zakłady budżetowe są jednostkami organizacyjnymi sektora finansów publicznych. Decyzję o ich utworzeniu, przekształceniu bądź likwidacji podejmują organy stanowiące j.s.t. Zakłady budżetowe nie posiadają osobowości prawnej ani zdolności sądowej, w stosunkach cywilnoprawnych reprezentowane są przez macierzyste j.s.t. Majątek gminnego zakładu budżetowego stanowi własność gminy ${ }^{11}$. Samorządowy zakład budżetowy prowadzi gospodarkę finansową na podstawie rocznego planu finansowego, obejmującego przychody (w tym dotacje budżetowe), koszty i inne obciążenia, stan środków obrotowych, stan należności i zobowiązań na początek i na koniec okresu oraz rozliczenia z budżetem j.s.t. (art. 15 ust. 1 ustawy o finansach publicznych ${ }^{12}$ ). Plany przychodów i kosztów zakładów budżetowych stanowią załącznik do uchwały budżetowej.

\footnotetext{
A. Borodo, Prawo budżetowe, Warszawa 2008, s. 165.

Ustawa z dnia 27 sierpnia 2009 r. o finansach publicznych (tekst jedn. Dz.U. z 2013 r., poz. 885 ze zm.), dalej: u.f.p.
} 
Zgodnie $\mathrm{z}$ art. 2 ustawy o gospodarce komunalnej ${ }^{13}$ wykonywanie zadań własnych przez jednostki samorządu terytorialnego w celu zaspokojenia zbiorowych potrzeb wspólnoty samorządowej (gospodarka komunalna) może być prowadzone w szczególności w formach samorządowego zakładu budżetowego lub spółek prawa handlowego. Zakres, w jakim zadania własne j.s.t. mogą być wykonywane przez samorządowe zakłady budżetowe, określony został $\mathrm{w}$ art. 14 u.f.p. Obejmuje on m.in. działalność w zakresie lokalnego transportu zbiorowego.

Samorządowy zakład budżetowy odpłatnie wykonuje zadania, dla realizacji których został utworzony, pokrywając koszty swej działalności z przychodów własnych. Co do zasady, zakład powinien organizować sprzedaż usług w taki sposób i według takich cen, które zapewniłyby mu samowystarczalność finansową ${ }^{14}$. Reguła ta nie ma jednak charakteru bezwzględnie obowiązującego. Działalność prowadzona przez samorządowe zakłady budżetowe, $\mathrm{w}$ tym w zakresie lokalnego transportu zbiorowego, obejmuje działania w sferze użyteczności publicznej. Świadczone przez nie usługi powinny być dostępne dla jak najszerszego kręgu odbiorców zamieszkujących gminę. Świadczenie usług na rzecz społeczności lokalnej często więc wykazuje charakter deficytowy, przychody osiągane z działalności nie bilansują się z zapotrzebowaniem na środki finansowe. Dlatego też niezbędne staje się wprowadzenie zewnętrznych źródeł zasilania finansowego, którymi są dotacje budżetowe ${ }^{15}$. Dofinansowanie za pomocą dotacji jest tym bardziej istotne, że w świetle art. 7 u.g.k. samorządowy zakład budżetowy nie może prowadzić działalności innej niż o charakterze użyteczności publicznej.

Zgodnie z art. 15 ust. 3-4 u.f.p. samorządowy zakład budżetowy może otrzymywać z budżetu jednostki samorządu terytorialnego:

- dotacje przedmiotowe, mające charakter dopłat do określonych rodzajów usług, kalkulowane wg stawek jednostkowych; w przypadku

13 Ustawa z dnia 20 grudnia 1996 r. o gospodarce komunalnej (tekst jedn. Dz.U. z 2011 r. $\mathrm{Nr}$ 45, poz. 236), dalej: u.g.k.

14 A. Borodo, Prawo budżetowe..., s. 165.

15 Zob. P.J. Lewkowicz, Komentarz do art. 15 u.f.p., [w:] E. Ruśkowski, J.M. Salachna (red.), Nowa ustawa o finansach publicznych wraz z ustawq wprowadzajqcą. Komentarz praktyczny, Gdańsk 2010, s. 103. 
usług publicznego transportu zbiorowego dopłata zazwyczaj jest kalkulowana w odniesieniu do 1 wozokilometra ${ }^{16}$;

- $\quad$ dotacje celowe na zadania bieżące finansowane z udziałem środków pochodzących z budżetu Unii Europejskiej, niepodlegających zwrotowi środków z pomocy udzielanej przez państwa członkowskie Europejskiego Porozumienia o Wolnym Handlu (EFTA) lub innych bezzwrotnych środków pochodzących ze źródeł zagranicznych;

- $\quad$ dotacje celowe na finansowanie lub dofinansowanie kosztów realizacji inwestycji (np. na zakup pojazdów);

- $\quad$ dotacje podmiotowe, w zakresie określonym w odrębnych ustawach.

Z brzmienia przepisów u.f.p. wynika w sposób jednoznaczny, że dotacje dla samorządowych zakładów budżetowych mają charakter fakultatywny. Dotacja udzielona z budżetu j.s.t. gminnemu zakładowi budżetowemu stanowi wydatek tej jednostki, który musi być zaplanowany w uchwale budżetowej. Jest to jednak transfer o charakterze wewnętrznym, gdyż przekazane środki pozostają w obrębie systemu finansowego gminy.

Dotacje dla samorządowego zakładu budżetowego, z wyłączeniem dotacji celowych, nie mogą przekroczyć 50\% kosztów jego działalności. Ograniczenie to wydaje się uzasadnione, gdyż dotacja budżetowa stanowić ma uzupełniającą formę finansowania działalności samorządowego zakładu budżetowego. Jeżeli dofinansowanie zakładu budżetowego dotacjami w granicach ustawowego limitu nadal jest niewystarczające, możliwe jest wykreślenie deficytowej usługi ze statutu zakładu, przekształcenie go w inną jednostkę organizacyjną (np. jednostkę budżetową) lub nawet zlikwidowanie $^{17}$.

16 Zob. np. uchwała nr XXIV/265/2012 Rady Miejskiej w Stargardzie Szczecińskim z dnia 18 grudnia 2012 r. w sprawie ustalenia wysokości stawki dotacji przedmiotowej dla Miejskiego Zakładu Komunikacji w Stargardzie Szczecińskim na 2013 rok. Uchwała ta przewiduje dopłatę do 1 wozokilometra w wysokości 2,8069702 zł (wozokilometr to jednostka długości drogi wykonanej przez pojazd w określonym przedziale czasu, np. roku), http://bip.um.stargard.pl/uchwaly/2012/2012-12-18/uxxiv-265.pdf (dostęp: 26 maja 2013 r.).

17 W. Lachiewicz, Jak finansować deficytowe usługi komunalne, „Gazeta Samorządu i Administracji” 2009, nr 8, s. 14. 


\section{4. Świadczenie usług w zakresie publicznego transportu zbiorowego przez utworzoną w tym celu spółkę komunalną}

Obowiązkowe zadania własne o charakterze użyteczności publicznej gmina może realizować za pomocą utworzonych w tym celu spółek prawa handlowego. Tworzenie spółek z udziałem samorządu terytorialnego regulują przepisy rozdziału 3 u.g.k. Na podstawie art. 9 tej ustawy, j.s.t. mogą tworzyć spółki z ograniczoną odpowiedzialnością lub spółki akcyjne, a także przystępować do takich spółek. Jeżeli samorząd realizuje określone zadanie $\mathrm{w}$ formule partnerstwa publiczno-prywatnego, zgodnie z ustawą z dnia 19 grudnia 2008 r. ${ }^{18}$, może utworzyć także spółkę komandytową lub komandytowo-akcyjną, w której podmiot publiczny nie może być komplementariuszem. Art. 19 u.p.t.z. nie przewiduje jednak wykonywania gminnych przewozów pasażerskich przy zastosowaniu instytucji partnerstwa publiczno-prywatnego.

Decydowanie o utworzeniu spółki lub przystąpieniu do już istniejącej (odpowiednio o rozwiązaniu lub wystąpieniu) należy do wyłącznej właściwości rady gminy, która podejmuje w tym przedmiocie stosowną uchwałę $^{19}$. Należy zauważyć, że spółka komunalna prowadząca działalność w zakresie publicznego transportu zbiorowego może powstać w oparciu o majątek zlikwidowanego zakładu budżetowego, który wcześniej realizował zadania gminy w tym zakresie ${ }^{20}$.

18 Ustawa z dnia 19 grudnia 2008 r. o partnerstwie publiczno-prywatnym (Dz.U. z 2009 r. Nr 19, poz. 100 ze zm.).

19 Art. 18 ust. 2 pkt 9 lit. f ustawy o samorządzie gminnym.

20 Zob. np. uchwała nr 173/11 Rady Miasta Torunia z dnia 8 września 2011 r. w sprawie przekształcenia zakładu budżetowego Miejski Zakład Komunikacji w Toruniu poprzez likwidację w celu utworzenia spółki Miejski Zakład Komunikacji w Toruniu spółka z ograniczoną odpowiedzialnością, http://www.bip.torun.pl/files/doc/173_11_01.pdf (dostęp: 26 maja 2013 r.). Podstawowym przedmiotem działania spółki utworzonej pod firmą Miejski Zakład Komunikacji w Toruniu spółka z o.o. jest wykonywanie zadania własnego Gminy Miasta Toruń mającego charakter użyteczności publicznej, polegającego na świadczeniu usług w zakresie lokalnego publicznego transportu zbiorowego. Zgodnie z uchwałą składniki mienia przekształconego zakładu budżetowego stały się majątkiem spółki i stanowią pokrycie kapitału. Spółka powstała w wyniku przekształcenia wstąpiła we wszystkie prawa i obowiązki związane z działalnością za- 
Spółki komunalne mają osobowość prawną, w obrocie prawnym funkcjonują jako samodzielne podmioty, odrębne od j.s.t. Spółka gminna wykonująca zadania z zakresu publicznego transportu zbiorowego jest przedsiębiorcą w rozumieniu przepisów o swobodzie działalności gospodarczej, ponieważ we własnym imieniu prowadzi działalność gospodarczą, tj. zarobkową działalność usługową, w sposób zorganizowany i ciągły $^{21}$. Spółki tworzone przez j.s.t. w sferze użyteczności publicznej nie są jednak podmiotami o charakterze typowo komercyjnym. Ich pierwszoplanowym zadaniem nie jest osiąganie zysku (choć mogą go osiągać), lecz zaspokajanie $\mathrm{w}$ interesie publicznym potrzeb należących do sfery zadań własnych j.s.t. ${ }^{22}$

Ponieważ konstrukcja spółki akcyjnej sprawdza się przede wszystkim w przypadku prowadzenia działalności na szeroką skalę, zaś proces jej tworzenia jest bardziej skomplikowany i wymagający większych nakładów finansowych, j.s.t. dużo chętniej korzystają z formy prawnej spółki z ograniczoną odpowiedzialnością. Według danych Ministerstwa Skarbu Państwa ${ }^{23}$ w 2011 r. j.s.t. utworzyły 132 spółki z o.o., 30 spółek akcyjnych i 33 zakłady budżetowe. Tworzenie spółek z o.o. miało zdecydowaną przewagę także w latach wcześniejszych ${ }^{24}$. W spółce jednoosobowej jedyny wspólnik (j.s.t.) wykonuje wszystkie uprawnienia przysługujące zgromadzeniu wspólników, zgodnie z przepisami Kodeksu spółek handlowych $^{25}$.

kładu, zaś pracownicy zakładu stali się pracownikami spółki w trybie art. $23^{1}$ Kodeksu pracy.

21 Art. 2 w zw. z art. 4 ustawy z dnia 2 lipca 2004 r. o swobodzie działalności gospodarczej (tekst jedn. Dz.U. z 2013 r., poz. 672 ze zm.).

22 E. Malinowska-Misiąg, W. Misiąg, Finanse publiczne w Polsce, Warszawa-Rzeszów 2006, s. 594.

23 Informacja o przekształceniach i prywatyzacji mienia komunalnego za rok 2011, Ministerstwo Skarbu Państwa, Warszawa 2012, s. 9, http://prywatyzacja.msp.gov.pl/download/5/8914/Informacja_2011.pdf, (dostęp: 26 maja 2013 r.).

24 Por. sprawozdania Ministerstwa Skarbu na temat prywatyzacji i przekształceń mienia komunalnego w latach 2002-2010, http://prywatyzacja.msp.gov.pl/portal/pr/26/Prywatyzacja_mienia_komunalnego.html, (dostęp: 26 maja 2013 r.).

25 Ustawa z dnia 15 września 2000 r. Kodeks spółek handlowych (Dz.U. Nr 94, poz. 1037 ze zm.). 
Problematyka prawno-finansowa działalności spółek samorządowych obejmuje nie tylko zagadnienia ze sfery prawa finansów publicznych, ale również europejskiego prawa konkurencji, gdyż wsparcie udzielone spółce przez j.s.t. może stanowić niedozwoloną pomoc państwa, grożącą zakłóceniem uczciwej konkurencji między podmiotami na rynku. Samorządowy zakład budżetowy, jako jednostka organizacyjna sektora finansów publicznych, ściśle powiązana z macierzystą j.s.t., może otrzymywać wsparcie w postaci dotacji budżetowych. Czy podobne dotacje z budżetu j.s.t. może otrzymywać spółka komunalna prowadząca działalność w zakresie publicznego transportu zbiorowego?

Przepisy zarówno u.f.p., jak i u.g.k. nie przewidują możliwości dotowania spółek, realizujących zadania w zakresie gospodarki komunalnej $^{26}$. Regulacji takich nie zawiera również ustawa o publicznym transporcie zbiorowym. W tej sytuacji przyjąć należy, że brak jest podstaw prawnych do udzielenia dotacji z budżetu j.s.t. spółce wykonującej zadania związane z publicznym transportem zbiorowym. W przypadku udzielenia dotacji spółce komunalnej, mogłaby ona zostać uznana za udzieloną nienależnie, tj. bez podstawy prawnej, i tym samym podlegać zwrotowi na rachunek budżetu j.s.t. wraz z odsetkami liczonymi jak dla zaległości podatkowych ${ }^{27}$.

Przyznanie dotacji mogłoby też stać w sprzeczności z art. 107 Traktatu o funkcjonowaniu Unii Europejskiej, zgodnie z którym wszelka pomoc przyznawana przez Państwo Członkowskie lub przy użyciu zasobów państwowych w jakiejkolwiek formie, która zakłóca lub grozi zakłóceniem konkurencji poprzez sprzyjanie niektórym przedsiębiorstwom lub produkcji niektórych towarów, jest niezgodna z rynkiem wewnętrznym

26 Zgodnie z art. 221 ust. 1 u.f.p. dotacja mogłaby zostać udzielona spółce, która nabyła status organizacji pożytku publicznego i nie prowadzi działalności nastawionej na zysk. Zob. uchwała SN z dnia 13 stycznia 2006 r., III CZP 122/2005, „Orzecznictwo Sądu Najwyższego Izba Cywilna” 2006, nr 12, poz. 200 oraz M. Cilak, Instrumenty wspierania rozwoju gospodarczego stosowane przez samorzq̨d terytorialny. Problematyka prawnofinansowa, Toruń 2013, s. 173-174.

27 Zob. też pismo Kolegium Regionalnej Izby Obrachunkowej w Szczecinie z dnia 27 lipca 2009 r., K-0542/55/UG/09, „Biuletyn Regionalnej Izby Obrachunkowej w Szczecinie” 2009, nr 3, s. 99-100, Lex nr 26535. 
w zakresie, w jakim wpływa na wymianę handlową między Państwami Członkowskimi.

Udzielanie dotacji samorządowemu zakładowi budżetowemu wiąże się z faktem jego nierentowności, z uwagi na świadczenie w interesie społecznym usług po cenach niższych niż wynikałoby to z rachunku ekonomicznego. Zgodnie z art. 8 ust. 1 ustawy z dnia 5 lipca 2001 r. o cenach $^{28}$, rada gminy może ustalać ceny urzędowe za usługi przewozowe w publicznym transporcie zbiorowym w zakresie zadania o charakterze użyteczności publicznej w gminnych przewozach pasażerskich. Ceny urzędowe mają charakter cen maksymalnych, chyba że przepisy odrębne stanowią inaczej. Ceny ustalone przez radę gminy obowiązują bez względu na to, czy podmiotem świadczącym usługi publicznego transportu zbiorowego jest samorządowy zakład budżetowy, czy też spółka komunalna. Jeżeli więc świadczeniem usług w zakresie publicznego transportu zbiorowego zajmuje się spółka utworzona przez j.s.t., pozbawiona możliwości otrzymania dotacji budżetowych, konieczne jest wprowadzenie specjalnego mechanizmu finansowania, umożliwiającego spółce prowadzenie działalności. Mechanizm ten stanowią rekompensaty z tytułu świadczenia usług publicznych. W świetle rozporządzenia (WE) nr 1370/2007 rekompensata obejmuje każdą korzyść, zwłaszcza finansową, przyznaną bezpośrednio lub pośrednio przez właściwy organ z funduszy publicznych w okresie realizacji zobowiązania z tytułu świadczenia usług publicznych lub powiązaną z tym okresem (art. 2 lit. g). Według art. 50 ust. 1 pkt 2 u.p.t.z. rekompensata przysługuje operatorowi (a więc spółce komunalnej) z tytułu:

- utraconych przychodów w związku ze stosowaniem ustawowych uprawnień do przejazdów ulgowych,

- $\quad$ utraconych przychodów w związku ze stosowaniem uprawnień do ulgowych przejazdów ustanowionych przez organizatora na obszarze jego właściwości,

- $\quad$ poniesionych kosztów w związku ze świadczeniem przez operatora usług w zakresie publicznego transportu zbiorowego; w tym przy-

28 Tekst jedn. Dz.U. z 2013 r., poz. 385. 
padku operatorowi przysługuje „rozsądny zysk”, rozumiany jako stopa zwrotu z kapitału, która w danym państwie członkowskim uznawana jest za normalną dla tego sektora i w której uwzględniono ryzyko lub brak ryzyka ingerencji organu publicznego ponoszone przez podmiot świadczący usługi publiczne ${ }^{29}$.

Aby rekompensata mogła zostać uznana za zgodną z zasadami wspólnego rynku, konieczne jest łączne spełnienie następujących przesłanek: przedsiębiorca musi być zobowiązany do świadczenia określonych usług, parametry służące do ustalania wielkości rekompensaty powinny być oparte na obiektywnych i przejrzystych kryteriach, wielkość rekompensaty nie może przewyższać kosztów poniesionych przy wykonywaniu danej usługi, uwzględniwszy oczekiwany przychód i rozsądny zysk, a jeśli procedura przetargowa nie była przeprowadzana, wysokość rekompensaty ustala się dokonując analizy kosztów, jakie poniósłby typowy, dobrze zarządzany i wyposażony w środki transportu przedsiębiorca, biorąc pod uwagę uzyskiwany przychód i rozsądny zysk ze świadczonych usług $^{30}$.

Kwestię dopuszczalności rekompensat przesądza wprost art. 9 rozporządzenia (WE) nr 1370/2007, stanowiąc, że rekompensaty z tytułu świadczenia usług publicznych w zakresie transportu pasażerskiego lub z tytułu dostosowania się do zobowiązań taryfowych ustanowionych zgodnie $\mathrm{z}$ ogólnymi zasadami ${ }^{31}$ wypłacane na podstawie rozporządzenia, są zgodne z zasadami wspólnego rynku i nie podlegają obowiązkowi notyfikacji Komisji Europejskiej.

\footnotetext{
Zob. pkt 6 załącznika do rozporządzenia (WE) nr 1370/2007.

Przesłanki te sformułował Europejski Trybunał Sprawiedliwości w wyroku z dnia 24 lipca 2003 r. w sprawie Altmark Trans GmbH, Regierungspräsidium Magdeburg und Nahverkehrsgesellschaft Altmark GmbH, C-280/00, Zbiór Orzeczeń 2003, s. I7747; M. Stasiak, Poproszę bilet... na koszt państwa. Pomoc państwa a rekompensata za usługi o charakterze powszechnym w transporcie drogowym, [w:] B. Kurcz (red.) Pomoc państwa. Wybrane zagadnienia, Warszawa 2009, s. 227-228.

31 „Zasada ogólna” oznacza środek mający zastosowanie w sposób niedyskryminacyjny do wszystkich usług publicznych tego samego rodzaju w zakresie transportu pasażerskiego na danym obszarze geograficznym, objętym właściwością miejscową właściwego organu (art. 2 lit. 1 rozporządzenia (WE) nr 1370/2007).
} 


\section{5. Świadczenie usług w zakresie publicznego transportu zbiorowego przez operatora wybranego w trybie przepisów Prawa zamówień publicznych lub ustawy o koncesji na roboty budowlane lub usługi}

Organizator może dokonać wyboru operatora w trybie ustawy Prawo zamówień publicznych. Przepisy u.p.t.z. wprowadzają w tym zakresie pewne regulacje szczegółowe, uwzględniające specyfikę przedmiotu zamówienia. Organizator, zgodnie z art. 23 ust. 1 u.p.t.z., zobowiązany jest do publikacji ogłoszenia o zamiarze przeprowadzenia postępowania o udzielenie zamówienia publicznego lub koncesji w terminie nie krótszym niż jeden rok lub sześć miesięcy - w przypadku, gdy umowa ma dotyczyć świadczenia usług w zakresie publicznego transportu zbiorowego w wymiarze mniejszym niż 50 tys. km rocznie. Ogłoszenie publikowane jest Biuletynie Informacji Publicznej, na stronie internetowej oraz w siedzibie organizatora i określa w szczególności rodzaj transportu oraz linie, na których będą wykonywane przewozy, a także datę rozpoczęcia postępowania o udzielenie zamówienia. Postępowanie najczęściej jest prowadzone w trybie przetargu nieograniczonego, zapewniającego największą konkurencyjność.

Zamówienie może dotyczyć jednej bądź kilku linii lub całej sieci komunikacyjnej. W specyfikacji istotnych warunków zamówienia (SIWZ) organizator może uwzględnić m.in. normy jakości i powszechną dostępność świadczonych usług, do których należą: liczba i rodzaj środków transportu wraz z zapleczem technicznym i niezbędną obsługą, rozwiązania techniczne sprzyjające ochronie środowiska, standard wyposażenia pojazdów, ich dostosowanie do przewozu osób niepełnosprawnych (art. 21 u.p.t.z.).

Organizator po dokonaniu wyboru najkorzystniejszej oferty, zgodnie z kryteriami określonymi w SIWZ (przy czym cena nie musi być jedynym i decydującym kryterium), zawiera z przedsiębiorcą umowę o świadczenie usług publicznego transportu zbiorowego w terminie 30 dni od dnia przekazania zawiadomienia o wyborze oferty. Umowa zawierana jest na czas oznaczony, nie dłuższy niż 10 lat $\mathrm{w}$ transporcie drogowym lub 15 lat 
w transporcie szynowym, innym niż kolejowy (tramwaje lub metro). Umowa zawarta z wykonawcą określa w szczególności:

- $\quad$ opis usług wynikających z zamówienia,

- $\quad$ wskazanie linii komunikacyjnych, po których będzie odbywał się transport,

- $\quad$ normy jakości w zakresie świadczonych usług,

- $\quad$ wymagania techniczne, jakie muszą spełniać środki transportu, którymi będzie wykonywany przewóz osób,

- $\quad$ sposób dystrybucji biletów oraz stronę umowy, której przysługują wpływy z tytułu opłat dodatkowych,

- $\quad$ zasady rozliczania kosztów świadczonych usług, z uwzględnieniem ulg ustawowych oraz ulg ustanowionych przez organizatora,

- $\quad$ sposób obliczania rekompensaty, zgodny z rozporządzeniem (WE) nr 1370/2007,

- $\quad$ warunki korzystania ze środków transportu organizatora, jeżeli zostały udostępnione operatorowi,

- zasady współpracy z operatorem przy opracowywaniu rozkładów jazdy,

- $\quad$ kary umowne,

- $\quad$ warunki zmiany oraz rozwiązania umowy.

Jeżeli płynność finansowa operatora jest zagrożona, jest on zobligowany niezwłocznie poinformować o tym fakcie organizatora. W przypadku niedopełnienia tego obowiązku lub utraty płynności finansowej, organizator może rozwiązać umowę bez wypowiedzenia.

Zapłata za usługi świadczone przez operatora wybranego w postępowaniu o udzielenie zamówienia publicznego należy do wydatków bieżących budżetu j.s.t. w zakresie zadań własnych. Wydatki te są finansowane przede wszystkim wpływami ze sprzedaży biletów ${ }^{32}$.

32 Zgodnie z art. 16 ust. 1 ustawy Prawo przewozowe pasażer zawiera umowę przewozu $\mathrm{z}$ organizatorem publicznego transportu zbiorowego przez nabycie biletu na przejazd przed rozpoczęciem podróży. Środki ze sprzedaży biletów komunikacji miejskiej (gminnej) stanowią dochody budżetowe zadań własnych gminy klasyfikowane w dziale 600 Transport i łączność, rozdział 60004 Lokalny transport zbiorowy. Przykładowo w uchwale budżetowej Miasta Torunia na rok 2013 wpływy ze sprzedaży biletów za korzystanie ze środków lokalnego publicznego transportu zbiorowego zostały określo- 
Zasady wyboru operatora $\mathrm{w}$ trybie koncesyjnym określa ustawa z dnia 5 lutego 2009 r. o koncesji na roboty budowlane lub usługi. Koncesjodawca zawiera umowę z koncesjonariuszem, który zobowiązuje się do wykonania przedmiotu koncesji za wynagrodzeniem. W przypadku koncesji na usługi stanowi ono wyłącznie prawo do wykonywania usług (w tym pobierania pożytków) albo takie prawo wraz z płatnością koncesjodawcy. Płatność koncesjodawcy na rzecz koncesjonariusza nie może prowadzić do odzyskania całości nakładów, jakie ten poniósł w związku z wykonywaniem koncesji. Rozkład ryzyka ekonomicznego obciąża bowiem w zasadniczej części koncesjonariusza (art. 1 ust. 3 ustawy). Koncesję można określić jako sui generis zamówienie publiczne, gdyż wiąże się $\mathrm{z}$ powierzeniem wykonania zadania publicznego podmiotowi trzeciemu, przy jednoczesnym nadzorze ze strony podmiotu publicznego. Zasadnicza różnica dotyczy jednak sposobu realizacji zadania oraz wynagrodzenia wykonawcy-koncesjonariusza ${ }^{33}$. Przenosząc konstrukcję umowy koncesyjnej na grunt usług w zakresie lokalnego transportu zbiorowego, w roli koncesjodawcy występuje gmina - organizator publicznego transportu zbiorowego, zaś koncesjonariuszem jest podmiot świadczący usługi transportowe w charakterze operatora.

Podmioty ubiegające się o koncesję, zgodnie z art. 13 ustawy, składają wnioski o zawarcie umowy oraz oświadczenia o spełnianiu wymagań określonych w ogłoszeniu (zdolność ekonomiczna i finansowa do realizacji zadania, posiadanie odpowiedniego zaplecza technicznego, wykwalifikowanych pracowników etc.). Koncesjodawca przeprowadza negocjacje z podmiotami, które spełniły wymagania formalne, a następnie zaprasza do składania ofert, przesyłając szczegółowy opis warunków koncesji. Wybrana zostaje oferta najkorzystniejsza, spośród ofert spełniających wymagania określone w opisie warunków koncesji, zgodnie ze wskazanymi kryteriami oceny (art. 17 ust. 1). Koncesjodawca zawiera umowę

ne na kwotę 41 mln 200 tys. zł (uchwała nr 456/12 Rady Miasta Torunia z dnia 13 grudnia 2012 r. w sprawie budżetu miasta na rok 2013, Dz.Urz. Woj. KujawskoPomorskiego, poz. 3792 ze zm.).

33 A. Panasiuk, Koncesja na roboty budowlane lub usługi. Partnerstwo publiczno-prywatne. Komentarz, Warszawa 2009, s. 28. 
z oferentem-koncesjonariuszem, która określa m.in.: przedmiot koncesji, okres obowiązywania umowy, termin wykonania przedmiotu koncesji, sposób wynagrodzenia koncesjonariusza, podział ryzyk związanych z wykonywaniem przedmiotu koncesji, normy jakościowe i standardy, które koncesjonariusz zobowiązany jest stosować.

\section{Podsumowanie}

Ustawa o publicznym transporcie zbiorowym wprowadziła cztery zróżnicowane formy prawne świadczenia usług lokalnej komunikacji zbiorowej. Organizator (gmina) może powierzyć ich wykonywanie samorządowemu zakładowi budżetowemu, spółce komunalnej, przedsiębiorcy wybranemu w drodze postępowania przetargowego lub udzielając koncesji. Z punktu widzenia prawa europejskiego nie jest istotne, czy usługi publicznego transportu zbiorowego będą świadczyły podmioty publiczne, czy prywat$n^{34}$. Wybór konkretnego rozwiązania zależeć będzie przede wszystkim od uwarunkowań lokalnych - charakteru gminy, jej powierzchni, liczby ludności itd.

Najsilniejsze związki organizacyjnoprawne i finansowe z macierzystą j.s.t. wykazuje samorządowy zakład budżetowy, który jest tradycyjną formą realizacji zadań z zakresu gospodarki komunalnej. Zakład budżetowy funkcjonuje w oparciu o przychody uzyskiwane z prowadzonej działalności, ponadto może otrzymywać dotacje z budżetu j.s.t. Jeżeli na koniec okresu sprawozdawczego wykaże nadwyżkę środków obrotowych, wpłaca ją do budżetu gminy, chyba że rada postanowi inaczej. Ta ustawowa zasada może oddziaływać na samorządowe zakłady budżetowe demotywująco i zniechęcać do efektywnego działania, choć z drugiej strony pamiętać należy, że celem działania zakładów budżetowych nie jest wypracowywanie jak największych zysków, lecz zaspokajanie potrzeb wspólnoty lokalnej.

Spółki komunalne utworzone w celu wykonywania gminnych przewozów pasażerskich posiadają osobowość prawną i są podmiotami odręb-

34 Punkt 12 preambuły rozporządzenia (WE) nr 1370/2007. 
nymi od j.s.t. W świetle obowiązującego ustawodawstwa brak jest podstaw prawnych, aby przekazywać takim spółkom dotacje budżetowe. Co więcej, tego rodzaju pomoc mogłaby zostać uznana za godzącą w interesy wspólnego rynku europejskiego. Ponieważ spółki komunalne nie są jednostkami sektora finansów publicznych, ich zobowiązania nie są wliczane do zadłużenia j.s.t., co dla gmin stanowi niewątpliwie korzystne rozwiązanie. Spółka komunalna stanowi podmiot wewnętrzny w rozumieniu przepisów rozporządzenia (WE) nr 1370/2007 i jest uprawniona do otrzymywania rekompensaty $\mathrm{z}$ tytułu świadczenia usług publicznego transportu zbiorowego (na pokrycie kosztów działalności spółki, w związku ze stosowaniem ulg ustawowych oraz ulg wprowadzonych przez organizatora na obszarze jego właściwości).

W trybie postępowania o udzielenie zamówienia publicznego lub udzielenie koncesji organizator publicznego transportu zbiorowego (gmina) dokonuje wyboru podmiotu, który będzie świadczył usługi publicznego transportu zbiorowego spośród przedsiębiorców, którzy złożyli oferty. Tryby te są najbardziej konkurencyjne spośród przewidzianych ustawą o p.t.z. Umowa zawierana jest z podmiotem, który przedstawił najkorzystniejsze warunki realizacji zadania. Wynagrodzenie wykonawcy stanowi bieżący wydatek budżetowy w zakresie zadań własnych gminy.

\section{Bibliografia:}

Borodo A., Prawo budżetowe, LexisNexis, Warszawa 2008.

Cilak M., Instrumenty wspierania rozwoju gospodarczego stosowane przez samorząd terytorialny. Problematyka prawnofinansowa, TNOiK, Toruń 2013.

Lachiewicz W., Jak finansować deficytowe usługi komunalne, „Gazeta Samorządu i Administracji” 2009, nr 8 (296), s. 13-15.

Lewkowicz P.J., Komentarz do art. 15 u.f.p., [w:] E. Ruśkowski, J.M. Salachna (red.), Nowa ustawa o finansach publicznych wraz z ustawq wprowadzajqcq. Komentarz praktyczny, ODDK, Gdańsk 2010.

Malinowska-Misiąg E., Misiąg W., Finanse publiczne w Polsce, LexisNexis Wyższa Szkoła Informatyki i Zarządzania z siedzibą w Rzeszowie, Warszawa-Rzeszów 2006. 
Panasiuk A., Koncesja na roboty budowlane lub usługi. Partnerstwo publiczno-prywatne. Komentarz, C.H. Beck, Warszawa 2009.

Stasiak B., Poproszę bilet... na koszt państwa. Pomoc państwa a rekompensata za usługi o charakterze powszechnym w transporcie drogowym, [w:] B. Kurcz (red.) Pomoc państwa. Wybrane zagadnienia, C.H. Beck, Warszawa 2009. 